Supplement of Proc. IAHS, 376, 25-33, 2018

https://doi.org/10.5194/piahs-376-25-2018-supplement

(c) Author(s) 2018. This work is distributed under

the Creative Commons Attribution 3.0 License.

(c) (1)

Supplement of

\title{
Water impacts and water-climate goal conflicts of local energy choices - notes from a Swedish perspective
}

Rebecka Ericsdotter Engström et al.

Correspondence to: Rebecka Ericsdotter Engström (rebecka.engstrom@energy.kth.se)

The copyright of individual parts of the supplement might differ from the CC BY 3.0 License. 


\section{Supplement}

\section{A. Calculation of the Water Footprint of Swedish Electricity}

In order to align and have corresponding data sources, this paper analyses data on emissions, water use, energy use and its

10 related water use for each of the 21 counties of Sweden for the year 2010. The Swedish electricity mix in 2010 is shown in table A1. The water requirement of each employed type of power generation was calculated as the sum of the water required (consumed) in the cultivation or extraction and processing of the input fuel before reaching the power plant (where applicable) and the water consumption rate (per unit of electricity produced) at the power plant.

Water consumption data comes from the same body of literature as mentioned in the main article. Data on consumptive water 15 use of electricity generation is collected from Averyt et al. (2011), Herath et al. (2011), Macknick et al. (2012), Mekonnen, Gerbens-Leenes and Hoekstra (2015) and Mekonnen and Hoekstra (2011). Employed water factors in this analysis, for total water requirements of electricity (fuel production and electricity generation phases), are shown in table A1. 
Table S1. Swedish electricity production year 2010 split on generation technologies (SCB, 2017), and estimated per water use for each technology.

\begin{tabular}{|c|c|c|c|}
\hline Plant type & $\begin{array}{l}\text { Electricity } \\
\text { production, } \\
2010(\mathrm{GWh})\end{array}$ & $\begin{array}{l}\text { Associated } \\
\text { water use } \\
\left(\mathrm{m}^{3} \mathrm{TJ}^{-1}\right)\end{array}$ & Water footprint data source and comments \\
\hline Hydropower & 66773 & 3600 & $\begin{array}{l}\text { Mekonnen and Hoekstra (2012). Geographical origin of data: Sayano } \\
\text { Shushenskaya reservoir, Russia - assumed to have similar evaporation } \\
\text { rates as Swedish hydropower }\end{array}$ \\
\hline Wind power & 3502 & 0,2 & $\begin{array}{l}\text { Mekonnen, Gerbens-Leenes, and Hoekstra (2015). Median value (this is } \\
\text { higher than most estimates). }\end{array}$ \\
\hline Solar power & .. & 19 & $\begin{array}{l}\text { Mekonnen, Gerbens-Leenes, and Hoekstra (2015). Median value (this is } \\
\text { higher than most estimates). }\end{array}$ \\
\hline $\begin{array}{l}\text { Nuclear } \\
\text { power }\end{array}$ & 55626 & 86 & $\begin{array}{l}\text { Gerbens-Leenes et al (2008). Only the water footprint of the input fuel is } \\
\text { included, since power plant cooling system uses seawater. }\end{array}$ \\
\hline $\begin{array}{l}\text { Combined } \\
\text { heat and } \\
\text { power } \\
(\mathrm{CHP}) \text { : }\end{array}$ & 19056 & & Sum of the below \\
\hline $\begin{array}{l}\text { CHP, } \\
\text { industry }\end{array}$ & 6242 & 4840 & $\begin{array}{l}\text { Calculated based on electricity production data from the Swedish } \\
\text { combined district heat and power plants (see Supplement section B) }\end{array}$ \\
\hline $\begin{array}{l}\text { CHP, } \\
\text { district heat }\end{array}$ & 12276 & 4840 & $\begin{array}{l}\text { Calculated based on electricity production data from the Swedish } \\
\text { combined district heat and power plants (see Supplement section B) }\end{array}$ \\
\hline $\begin{array}{l}\text { Condense } \\
\text { prod. (oil) }\end{array}$ & 517 & 385 & $\begin{array}{l}\text { Sum of Power plant cooling water use from Averyt et al. (2011) and } \\
\text { Input fuel water footprint from Rio Carrillo \& Frei (2009) }\end{array}$ \\
\hline $\begin{array}{l}\text { Gas turbines } \\
\text { (oil) }\end{array}$ & 21 & 385 & $\begin{array}{l}\text { Sum of Power plant cooling water use from Averyt et al. (2011) and } \\
\text { Input fuel water footprint from Rio Carrillo \& Frei (2009) }\end{array}$ \\
\hline
\end{tabular}

\section{B. Calculation of the Water Footprint of Swedish District Heat}

5 Data on fuels burned for Swedish district heat production are available for each municipality from Energiföretagen (n.d.). Data for 2010 shows a majority of input fuels coming from renewable sources, primarily biomass and waste. The indirect water consumption of district heat production is calculated based on reviewed water use per fuel data multiplied with the percentage share of each input fuel (in 2010). Added to this is the direct water requirements of the district heating itself, estimated in this study to the annual volumes of make-up water divided by total heat delivery for the same year. Make-up water data are not

10 publically available for the Swedish district heating systems in general. For this study, data on the direct water use was obtained for a selected, considered typical, system - the Oskarshamn municipal district heating system - and used as a proxy for average Swedish conditions. Worth noting related to this estimate is the difference in scale between indirect water (from fuels) and the 
direct water (make-up water within the district heat system) volumes. The latter is only approximately $10^{-3}$ compared to the former.

\section{Accounting for transmission losses in the energy system}

Unless otherwise stated, data on water requirements for fuel, heat and electricity production are assumed to be in units of fuel

5 produced. The present study uses these data to investigate the implication on fuels etc. consumed. To acknowledge this discrepancy, transformation and distribution losses in the energy system between primary/secondary and final energy are included in the water-for -energy calculations. Data on losses in the electricity system are estimated to $7.13 \%$ for year 2010 and come from the IEA data table on "Electric power transmission and distribution losses (\% of output)" C OECD/IEA, 2010, (filtered on data for Sweden) www.iea.org/statistics (Licence: www.iea.org/t\&c).

10 The efficiency of Swedish district heat production system is reported to $96 \%$, (Energiföretagen, n.d.) and system losses are calculated to on average $11 \%$.

Distribution of liquid, solid and gas fuels, whether renewable or not, are considered to have negligible losses.

\section{Additional figures}

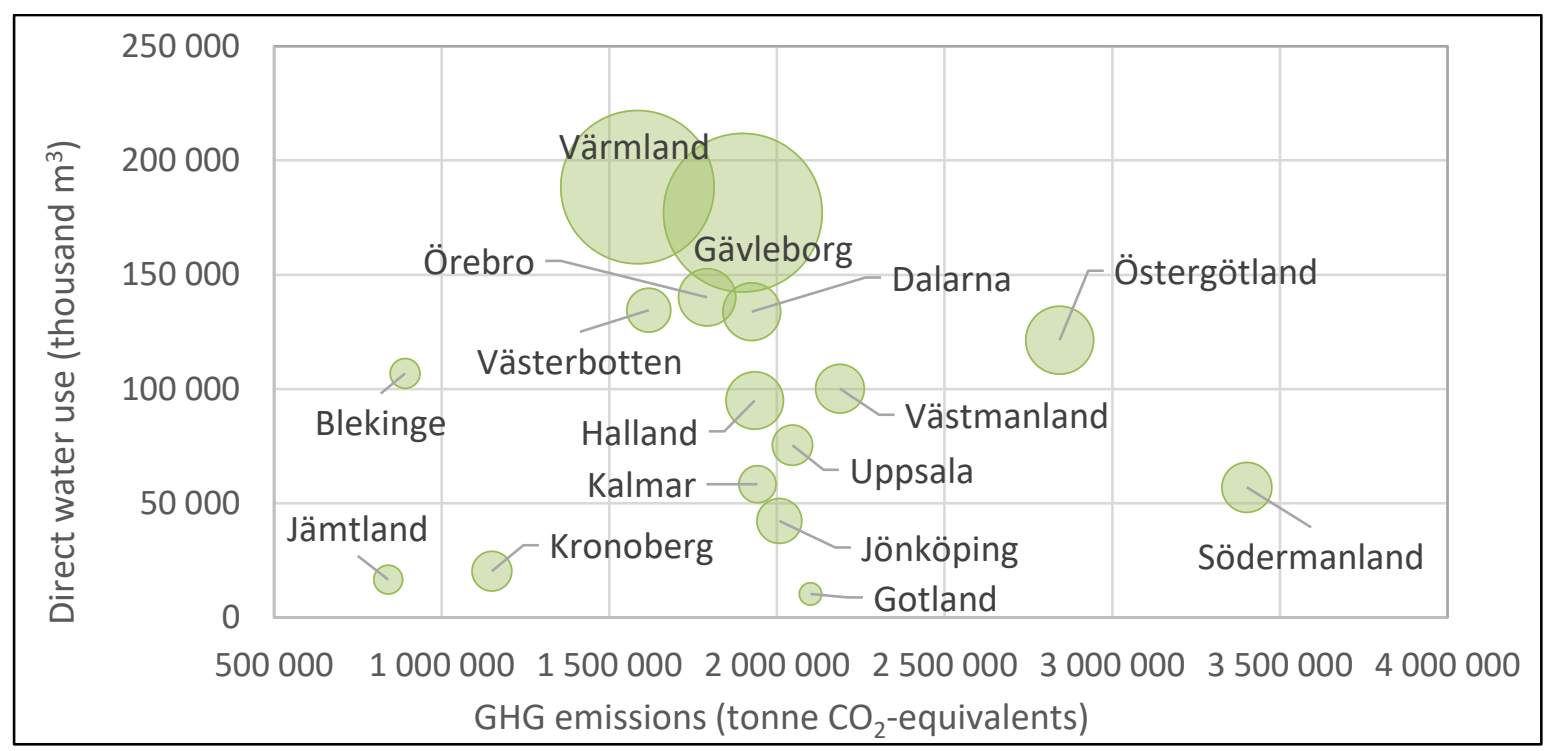

Figure S1: Zoom-in of the left lower corner of main manuscript's figure 2 (absolute GHG emissions (x-axis), direct local water use (y-axis) and indirect-remote water use for energy supply (circle size) in Swedish counties). 


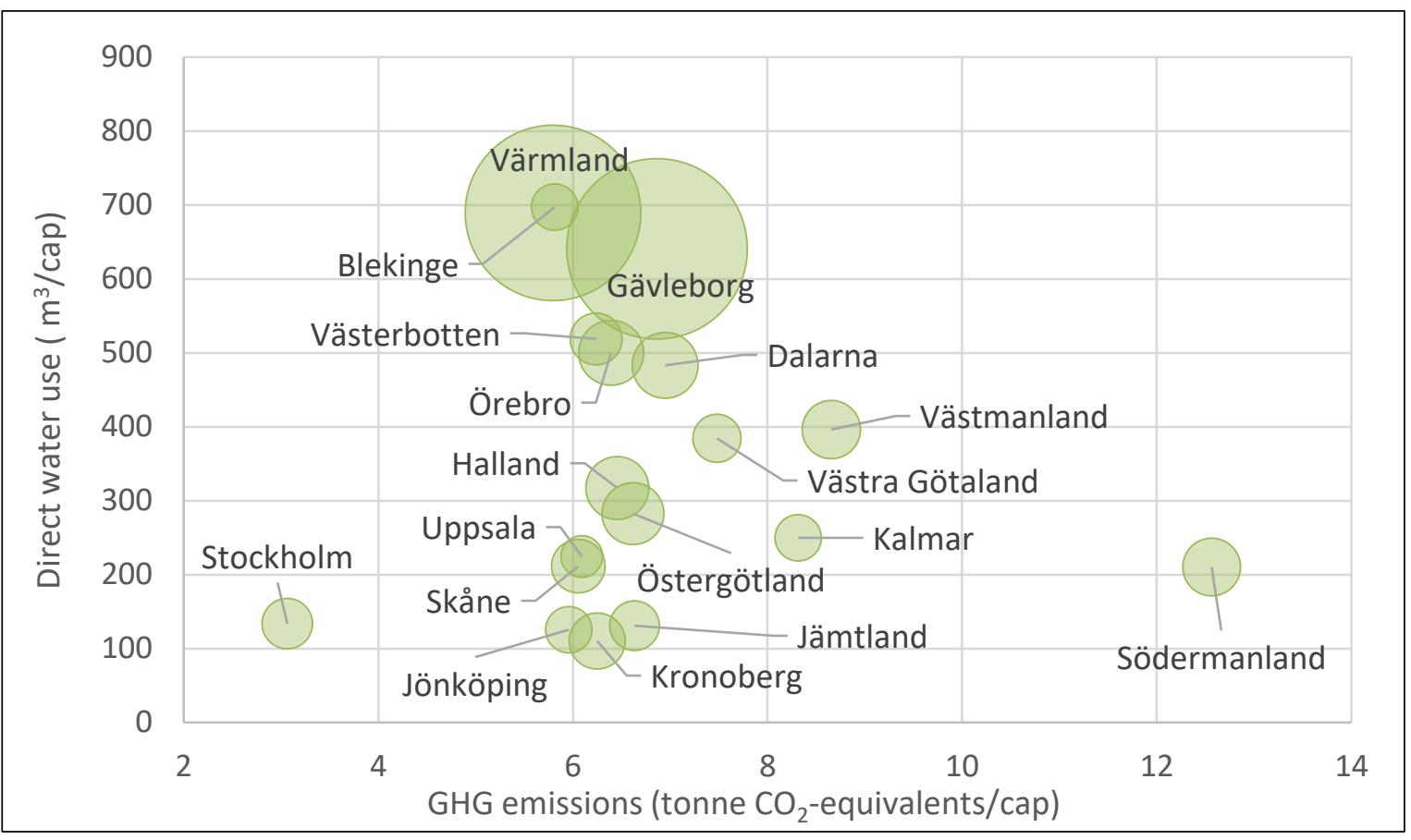

Figure S2: Zoom-in of the left lower corner of main manuscript's figure 3 (per-capita GHG emissions (x-axis), percapita direct local water use (y-axis) and per-capita indirect water use for energy supply (circle size) in Swedish counties).

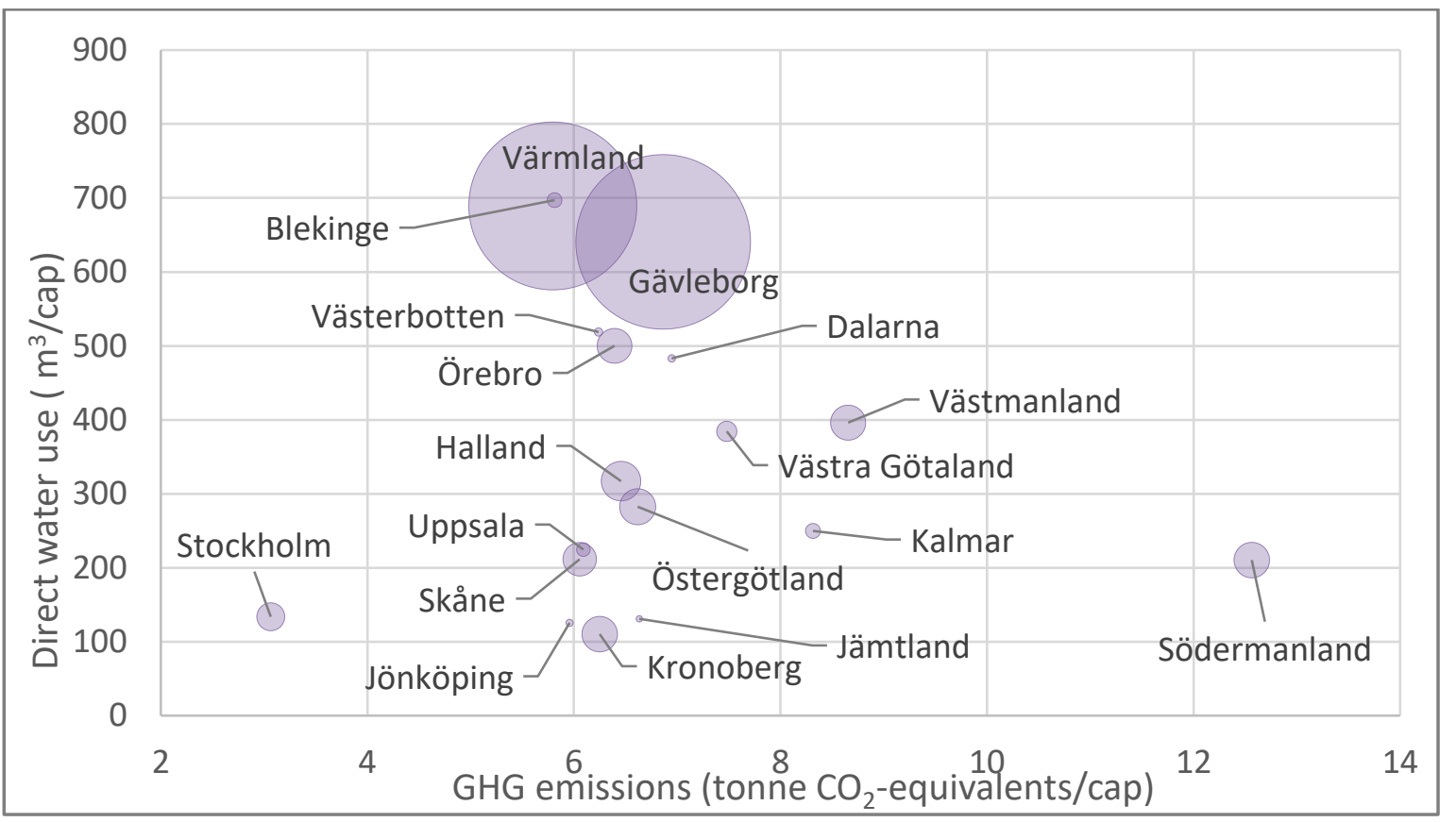

Figure S3: Zoom-in of the left lower corner of main manuscript's figure 3 (imported" indirect water use outside of Sweden related to the population (per-capita units) and the energy use in Swedish counties, compared to reported direct water use per capita (y-axis) and GHG emissions per capita (x-axis)). 


\section{Supplement References}

Averyt, K., Fisher, J., Huber-Lee, A., Lewis, A., Macknick, J., Madden, N., Rogers, J., and Tellinghuisen. S.: "Freshwater Use by U.S. Power Plants: Electricity's Thirst for a Precious Resource." A report of the Energy and Water in a Warming World initiative. Union of Concerned Scientists, 2011. Available at: http://www.ucsusa.org/clean_energy/our-energy-

5 choices/energy-and-water-use/freshwater-use-by-us-power-plants.html, last accessed: 10 October, 2017

Gerbens-Leenes, W., Hoekstra, A. Y., \& van der Meer, T. H.: "The water footprint of bioenergy and other primary energy carriers." (Value of water research report series 29; No. 29). Delft, The Netherlands: Unesco-IHE Institute for Water Education 2008, available at: https://ris.utwente.nl/ws/portalfiles/portal/5148108, last accessed: 10 October, 2017

Herath, I., Deurer, M., Horne, D., Singh, R., and Clothier, B.: "The Water Footprint of Hydroelectricity: A Methodological

10 Comparison from a Case Study in New Zealand." Journal of Cleaner Production 19 (14): 1582-89. doi:10.1016/j.jclepro.2011.05.007, 2011.

Macknick, J., Newmark, R., Heath, G., and Hallett, K. C.: "Operational Water Consumption and Withdrawal Factors for Electricity Generating Technologies: A Review of Existing Literature.” Environmental Research Letters 7 (4): 045802. doi:10.1088/1748-9326/7/4/045802, 2012.

15 Mekonnen, M. M., and Hoekstra, A. Y.: "The Blue Water Footprint of Electricity from Hydropower." Hydrology and Earth System Sciences 16: 179-187, doi:10.5194/hess-16-179-2012, 2012.

Mekonnen, M. M., Gerbens-Leenes, P. W. and Hoekstra, A. Y.: "The Consumptive Water Footprint of Electricity and Heat: A Global Assessment.” Environmental Science: Water Research \& Technology 1 (3): 285-297, doi:10.1039/C5EW00026B 2015 .

20 Rio Carrillo, A. M., and Frei. C.: "Water: A Key Resource in Energy Production." Energy Policy 37 (11): $4303-12$. doi:10.1016/j.enpol.2009.05.074. 2009.

SCB (Statistiska Centralbyrån) "Slutanvändning (MWh) efter region, förbrukarkategori, bränsletyp och år” [Electronic resource], Table: EN0203AE10, Accesible:

http://www.statistikdatabasen.scb.se/pxweb/sv/ssd/START EN EN0203/SlutAnvSektor/table/tableViewLayout1/?rxid=b

25 5ed1707-95ec-43cc-8e49-86931b6a2267 [2017-09-30]

Energiföretagen, n.d. Data table: "Fjärrvärmens bränslen och produktion 2010" [Electronic resource] Accessible: https://www.energiforetagen.se/statistik/fjarrvarmestatistik/tillford-energi/tillford-energi-till-fjarrvarme-och-

kraftvarme/ [2017-09-31] 